\title{
ECONOMIC VALUES IN THE CONSTITUTIONAL PREAMBLES
}

\begin{abstract}
The economic values and categories within the constitutional preamble appear in this work as a subject of the special interest. In the contrast to the primary center of gravity of classical legal thought when it researches the constitutional preamble, the pendulum will be slightly shifted towards questionable of position and the way in which constitutional preambles regulate issues of economic values and categories. We do not regard this question less significant compared to the usual literary manners of preamble study. It is our understanding of the importance of constitutional attitudes towards to the vital issues of the state and security that started us to begin exploring of this problem, in the context of an established thematic framework of this paper. There is no doubt that legislators in the preambles treat various issues in different ways, depending on the gravity of priority. Rarely, we could find constitutions without preambles, constitutions with technical preambles and with preambles, almost entirely, faced toward the past. However, for this paper is interesting preambles which texts could be characterized as a futuristic projection and perspective, because, among them we want to find the essence of the legislators' attitudes to economic issues.
\end{abstract}

Key words: preamble, constitution, law, economic value, economic justice

JEL Classification: K10, K30, K40

\section{ЕКОНОМСКЕ ВРЕДНОСТИ У УСТАВНИМ ПРЕАМБУЛАМА}

\section{Апстракт}

Као предмет посебног предметног интересовања у овом раду појављују се економске вредности и категорије у оквирима уставних преамбула. За разлику од примарног тежишта класичне правне мисли када се бави истраживањем уставних прембула, клатно ће бити благо померено ка упитаности позиције и начина на који се уставним преамбулама регулишу питања економских категорија и вредности. Ово питағе не сматрамо никако мање значајним у односу на уобичајене литерарне манире проучаваьа преамбула. Управо наше разумевање значаја ставова уставотворача према виталним питањима државе и друштва нас је и покренуло да се позабавимо овим проблемима, у контексту успостављеном тематским оквиром овог рада. Нема сумње да се преамбулама уставотвории опходе према разнии питањима на различите начине, у зависности

\footnotetext{
${ }^{1}$ sdjordjevic@jura.kg.ac.rs
} 
од тога чему ће давати степен тежниног приоритета. Истина ређе, наићиће се и на уставе без преамбула, на уставе са техничким преамбулама, као и на уставе чије су преамбуле окренуте, готово у целости, ка прошлости. Медјутим, за овај рад су интересантне оне преамбуле, чији се текстови могу окарактерисати као футуристичке пројекиије и перспективе. Јер, међу њима се жели открити суитина ставова уставотвораиа у односу према економским питањима.

Кључне речи: преамбула, устав, право, економске вредности, економска правда.

\section{Introduction}

Consideration of the preamble could be multiple useful from the stand point of the Constitutional law. On the one hand, man gets the general impression of the structural composition of the constitutional text, and it is expedient to answer on the question about the number of constitutions that contain preamble, in order to reach standardized formulas of technical structuring a constitutional text. Respectively, the proportion between constitutions that contain preambles and those who does not, is indicator of popularity of this method of the beginning of constitutional texts. Taking into account the current situation, there is noticeable general tendency towards existence of preambles, including the exceptions that do not jeopardize the acquisition of general conclusion. In addition, thanks to the operational efficiency of the use of the available material on the Google search engine, all positive legal texts are readily available (www.constituteproject.org). Around thirty constitutionalists of the total number (194) opted not to enrich their texts with specific preamble. Of course, this information is accurate in the extent that is not relativized by the dynamism of constitutional changes, because it can mean different nomotechnical approaches of constitutionalists. Thus, for example, the preamble in their constitutions has Sweden, Netherlands, Mexico, Uruguay, El Salvador, Denmark, Oman, Yemen etc. the significance of the preamble does not jeopardize a data about very small number of the constitutions which preambles highlight only certain technical details, such as various forms of the constitutionalists.

On the other hand, the preambles of the constitutions of the constitutional states become "text-event" (Häberle, 2000, p. 50), command attention on several grounds, both in the formal-technical and linguistic terms, and regarding to the inner content. We will this textual-legal emergence treat under auspices of the law. However, that view will be enriching with the knowledge of the economic issues that are object of the preambles.

On this occasion, the first impression that arises after the analysis of the preambles of the positive legal constitutions is a little different compared to the current position of the economic issues within the normative parts of the constitutional texts. Except in the preambles, modest presence of economic values, problems and categories can be recorded in the normative framework of the constitution (Purić, Djordjević, 2014). Economic values in many different ways occupy a position in the legal and normative framework. When it comes to the constitution as a highest legal act, we notice that there is a couple of level positioning of economic values and categories. Economic arrangement, as an integral part of the general social order, is indispensable ingredient 
of constitutional norms. In the constitutional academic literature is enough emphasized specific way of the constitutional regulation of economic matters, so, there is no need for repeating. It is sufficient to point out that the economic rights and freedoms belong to the overall corpus of human rights and freedoms. For the introductory remarks and methodological approach to the central theme in this paper, it is less important to say that economic rights and freedoms often appear as an inseparable part of the socio-economic rights and freedoms. In fact, it became customary and standard style of constitutional language that economic rights and freedoms do not occupy an autonomous position in the classification system of human rights, but are primarily associated segment of wider thematic unit - the socio-economic rights and freedoms. Probably in line with the general orientations that economic issues are less widespread compared to the other parts of social life. Constitutional legal theory follows this state of affairs, within the positive legal solutions. Recent studies on the theme of form and structure of preambles do not deviate from the habit of neglecting indicated economic thesis, which is easy to spot (for example, Vukas, 2013). Therefore, it is advisable to recall the necessity of combining various fields of scientific knowledge, as one of the "clearly defined tendency in the development of modern science" (Hafner, Krstić, 2014, p. 156).

\section{The interpretation of the modern constitution's preambles}

A need to pay special attention to issues from the subject matter covered by the title of paper derives from the fact of development of an interpretation system of constitutional issues. Definitely, we have to treat non-normative part of constitutional text on the specific way, like preamble, in relation to the normative part. Methods of interpretation of the constitution can no longer be understood in a general way, so it is crucial to precisely differentiate them to the specific areas. In the case of the preamble, "their interpretation has to be specific, discover the cultural depth dimension, they have to be distinguished from others, more formal complex norms" (Häberle, 2000, p. 83). However, the proces of understanding the preamble, in the sense of „cultural depth dimension", submits new requirements for the distinction in the interpretation, which is consequence of the pecularities of certain ideas that belong to the preamble. Such diferencies we can observe in the occasion of economic ideas in relation to those that we could call political, like history, nation, tradition, human rights, rule of law, democracy etc. In relation to all marked ideas, a history has a signifacant place, which is suggested often in the academic literature (Bačić, 2013). On the other hand, with a great amount of highlighting of "historical beliefs", we should be especially careful, because "their influence can prevent us to face with daily tasks of social life" (Popper, 1993, p. 27). In addition, of course, we are aware of the uniqueness of social life, which brings together the totality of many different segments of the social relations, facts and forces, functions and mechanisms. Without insisting on the dualism of economics and law, experience of constitutionlist's expresion of attitudes regarding to basic social values, however, points out to the particularity of the position of the economy in the texts of the preambles.

Note that has to be emphasized concerns the conceptual understanding of constitutional letters style, esspecialy when we are on the specific field, such as preambles. Corpus of human rights and freedoms is almost universal and „favorite“ place of the 
constitutionalists. According to the principle of the abstracted linguistic skills, appropriate to the purpose of the preamble, under the legal-political expressions of human rights and freedoms, we should bear in the mind the group of economic, respectively, socio-economic rights and freedoms. This fact brings us to the general conclusion about the participation of economic values whenever evasive formulas indicate human rights and fredoms in the language of the constitution. So, when economic values are not explicitely allocated with its specific language positioning, always when we are faced with the term of human rights and freedoms have to imply them hypothetically. Similarly, when this term is even more qualified legally, ie, when there is indicated international legal documentation, which regulate human rights and freedoms, it is acceptable to have in mind the relevant international legal acts that regulate economic values. Along with this clarification, it is necessary to draw attention to the different possibilities of understanding of some basic and essential rights and freedoms. Thus, for example, taught with the experiental messages of application of human rights, it can be emphasized human dignity, where we could always ask for the role of economic sphere of human society in a structural understanding of the concept of human dignity.

Previous hermeneutic notes about understandind a meaning of certain statement from the preambul's texts in the context of the considered economic values, aims to convince us in their indispensable presence within constitutional preambles. But, on the other hand, it is research interest to determine the quality and extent of the special recording of economic values observed in the constitutional texts. Here we can find an autonomy due to the orientation that constitutionalists who estimated a need for particular emphasis and indication of certain economic values. Thereby, constitution-makers admit that the flat of their views on the present and future has to enrich with economy, putting it in a parallel with the political, cultural, ethnic and social vision of community that is constituted by the constitution.

However, the recent studies confirm our superior starting attitude on the restrictive position of economic values within constitutionalists' orientations, which they show through the preambles as a means of the expressing their own ideas. Thus, for example, among the typical values in the preambles they emphasize "the sovereignty, independence, integrity, democracy, rule of the law, social justice, freedom, equality and human rights" (Kultešić, 2010, p. 72). Of course, such situation does not prevent analysis of the preamble in which they can identify the economic values and categories, in addition to the typical. For this purpose, it will not be discussed preambles, which we tend to call "technical", because their texts are not burden by different social values, but certain technical details (for example: the bringer of the constitution). Quite expectedly, leaving aside the preamble in which we cannot register economic values. Such are, for example, preambles of the constitutions of Albania, Andorra, Argentina, Armenia, Bahamas, Bahrain, Belarus, Benin, Bhutan etc (www.constituteproject.org). Finally, preambles suitable for the analysis are preambles where we could discover certain parts of the economic themes, which is between 50 and 60 in relation to the total number of the 194 modern constitutions. These are, for example, the preamble of the constitutions of the Afghanistan, Algeria, Bangladesh, Barbados, Bosnia and Herzegovina, Cameroon, China, Sri Lanka, Spain, Slovakia, South Korea, Papua New Guinea, Pakistan, Nicaragua, Nepal, Namibia, Morocco, Madagascar, Macedonia, Cuba, Colombia, Iran, India, Honduras etc (www.constituteproject.org). Among them, may be encountered 
in the specific preambles' statements, which contains a catalog of fundamental human rights and freedoms with a normative type of linguistic expression, as is the case in the preamble of the Constitution of Cameroon.

\section{The economic content of the constitutional preambles}

Acceptable Häberle's general argument that the constitutionalists entries "that part of the fruitful tension between desire and reality in the constitution" (Häberle, 2000, p. 186), with equal importance can also refer to the considered position of economic categories in the preambles of constitutional texts. Namely, the starting center of gravity on which the most legal scholars base previously specified position, is located in the sector of human rights and freedoms, and others, primarily, political values. In addition, as per an acquired habit, one can overlooks that in the structure of depth of the collective consciousness of a community that expresses the power of the constitution of the state, is present intimately experiencing of economic condition of common life. The identification of this experience is difficult, due to the strength of the public argumentation about other values, such as nationality, faith, religion, politics, traditions, etc. The present situation is obviously the result of previous human experience about understanding of social life; in this experience is leading the importance of political values. Nevertheless, it is necessary to bear in mind a theoretical attitude of social life, which is always necessarily regulated in such a way set by people, and it makes a unity where we could always find - according to the specific actions by the individual members of the legal community - both moments, economic and political activity that in the mutual correlation could be distinguished (Štamler, 2001, p. 279). Certainly, in the opening constitutional textualisation of the most relevant values, could be registered the separation political from economic phenomenon, whereby those first occupy a dominant position. However, with careful analysis of the positive legal texts of the preambles, of the individual's state constitutions, we can derive a few conclusions.

On the first place, it is prevalent impression that economic issues are not significant subject of the expression of the constitutionalists within preambles. This is supported by the fact that, roughly, more than half of the existing preambles in the modern constitutions do not contain a commitment of the constitutionalists to the economic issues, categories and values.

Second, in the preamble's texts, which creators decided to incorporate economic issues, it seems to be in a more modest way in relation to the preponderance of issues from the political spheres of social life. And it, on the one hand in the view of restrictions of the text devoted to the economy, and on the other hand, in a terms of the stylistic expression, which takes a character of less "lofty goals", primarily focused in the relation to the political issues. However, regardless on the discernible modesty of constitutionalists in relation to the economic parts of the preambles, it seems that they still have an awareness that their futuristic projections prevent "forced realization of economic processes" (Bataveljić, 2012, p. 228).

When we talking about these preambles, we can extract the following economic categories that constitution-makers consider particularly important, so they stand out and emphasize them, by placing in the "pre-textual space": 
- strengthening economic institutions (Afghanistan), economic development (Algeria, Bosnia and Herzegovina, China, Slovakia etc) and economic prosperity (Barbados, Bosnia and Herzegovina, Macedonia etc);

- economic order as an integral part of the social order, which exists in the parallel with the political order (China, Colombia, Zambia etc); market issues, commitment to the market economy, free market (Bosnia and Herzegovina, Angola etc);

- the importance of the economics for other values in the society (the functioning of the economic system in the function of common good (Dominica, Barbados, Belize etc), individual freedoms depend from the economy (Sri Lanka);

- Economy as the basis of relations with other countries in terms of economic exchanges with other countries, economic integrations and economic freedoms of the states. This is an example of the constitutional preamble of Burkina Faso in relation to integration within the framework of Africa, or the constitutional preamble of Colombia in relation to Latin America. Framers of the constitution of Haiti, however, express commitment to strive towards economic free nation;

- Particularly notable are the constitutionalists' attitudes about different experiences of economic justice: the elimination of the economic privilege, economic equality, fair economic order, fair distribution of the earned revenues, and economic reward for the work. A value category of economic justice in various textual formulations may be seen in the preambles of, for example, Spain, Pakistan, Belize, the Solomon Islands, Papua New Guinea, and Nicaragua.

Of course, freedom of constitutionalists' actions during the defining of the contents these types of theirs texts are sufficiently imminent and it is very hard to establish appropriate standards. What we can to do is to recognize a dominance of certain economic issues, which constitutionalists incorporate in the texts of the preambles. Because, thus we simultaneously acquire a special view on the significant economic values that have taken place especially in the constitutionalists' visions about perspectives of development of social communities, constituted by constitutions. Pursuant non-normative essentiality of the preamble, a constitutionalist sets sum of ideas in it, which are, by his opinion, the most relevant for the survival of the community embodied in the form of the established states. With respect to such preambles, in their texts we can essentially reveal a specific dimension of oscillatory message, which is carried by moral norms, aiming high targets, with a refusal to punch an ethical minimum. That is why ethical freedom of the creators of the constitutions have a much wider scope, when they are on the field of the preambles in relation to space of classical, binding legal norms. Respecting the freedom of the constitutionalists during the creation constitutional provisions, the treatment of individual preamble's texts will be always connected with certain specifics of the objective social circumstances in which constitution are designed. In that moment, the constitution-makers can act suprarationally, i.e., irrationally, just as they do when people autonomously determine their priorities for moral behavior (Pečečin, 2014, p. 34). For these reasons, our consideration of potential standardization certain solutions of the application of economic categories in preambles are the result of 
the individual experiences connected and gathered at the global level. It is very difficult, at the first glance, to establish common denominators that would be generally applicable to all constitutional orders in the presence of the economic issues in the analyzed texts. Therefore, as a concluding results appear sublime performances based on the gathering of the, so-called, common denominators in the preambles of the various individual states. At the same time, we are aware of axiomatic Smith's attitude, which we keep in mind due to the social literature, that "every system of positive law can be evaluated as more or less imperfect attempt of realization of a system of a science of natural justice or attempt of enumeration of specific principles of justice" (Jelić, 2010, p. 659).

Our attention is attracted by economic justice, as one of the major constitution definitions toward this ideological value. It is essential to ask whether the result of the justice can be compatible with economic values, if we from the conceptual understanding of justice excommunicate its economic dimension. However, treatment of justice is a very complex mental activity, because the concept is content-rich and multifaceted, which is the reason more in supporting the necessity of additional intellectual caution. Along with the transformation of organized society in the form of modern state, flowed the process of transformation of human consciousness about dominant perception of justice. "Justice as fairness seems to require us to aim directly to satisfy principles even when doing so consistently guarantees failure" (Brennan, 2007, p. 297). It seems that it is in the modern state, in fact, a flash reconvalescence ancient Greek idea about the necessity of being perceived through the formula of equitable distribution of goods in relation between individuals, and also in the organized community with organized way of life. Of course, it is true that modern social thought devoted to justice placed through the wide array of different directions, but we will not deal with its presentation, because we need to focus on the central theme of this paper. It is notable that the problem of economic justice in the minds of the constitutionalists is experiencing through the several conceptual directions, which are almost always based on the idea of equality, as gravity and universally valid principle, which establishes understanding of the purpose of social relations. Therefore, a wide spectrum of different sub-themes belongs to the framework of economic justice in the treated preambles, such as economic equality, fair economic order, economic reward for the work, the fair distribution of earned revenues, the elimination of economic privileges. All these ideas that are scattered throughout various preambles' parts of constitutional texts of individual states are connected on the level of the general understanding of justice, in the sense of the ancient Greek concept of justice as equitable distribution of totality of common goods, produced within community. This, long-standing Aristotle's conception of justice, is still not overcame, so, under his thoughts can fall attitudes of the contemporary constitutionalists on their understanding of economic justice.

\section{Conclusion}

After the completion of the research analysis of the described problem, we can draw some basic conclusions. Among them, special attention should be paid to the fact of insufficient interest among actors in the field of legal science to devote more attention to dealing with the problem of mutual interpenetration of legal and economic problem. There 
is no doubt that one of these positive legal positions is a problem shown in this paper. On the other hand, it seems to be necessary to encourage laborers of the economic thought to explore these issues. As Hayek pointed out: ,there is almost no problem that cannot be adequately answered on the basis of only one specialized discipline...", because, "an economist who is only an economist cannot be a good economist“" (Stojanović, 2006, p. 170).

Besides the necessary encouragement to the multidisciplinary nature in order to obtain objective performance of the treated phenomena, we could acquire the requirements for advanced reasoning. In relation to the dominant models of the constitutional preambles and their criteria, it is reasonable to establish additional criteria, from the standpoint of position economic value, categories and questions within the preamble's text statements. Of course, like all other classifications, in this case, the methodological purpose is two-fold: the first one is to get transparent representation of the position of the indicated issues in constitutional preambles of modern states; the second one understands the essential features of the preamble in order to define a nature of concrete preamble in the constitution of each modern state. Along with the acquisition of the image of the inner preamble content, we could find another image - an image about constitutionalist's orientation in relation to the key issues of social life in the community, which is constituted by constitution in the form of the state. That will be particularly important and foundational issues, without whose identification there is neither constituted community. Summing up the results of the research, it is evident that the constitution-makers believe that the economic value and categories are less important in relation to the problem of history, politics, tradition, culture, human rights, symbols... However, it is necessary to emphasize the fact that about a quarter of the total number of contemporary constitutionalists did not miss an opportunity of recording economic issues, which are incorporated in the text of constitutional preambles. This fact seems sufficiently stimulating to be a subject of the relevant scientific research, so it would be expedient that legal and economic sciences devote more attention, in the separate and in the joint research efforts.

\section{References}

Bačić, A. (2013). Constitutionalism, Historicism and Postmodernism, Proceedings of the Faculty of Law in Split, vol. 50, 1.

Bataveljić, D. (2012). The Relation between Law and economics, Legal and Infrastructural Basis for the Development of Knowledge-based Economy, Kragujevac, 2012, pp. 217-241.

Brennan, J. (2007). Rawls' Paradox, Constitutional Politic al Economy, December 2007, Volume 18, Issue 4 pp. 287-299.

Vukas, B. (2013). Historic-law References in the Constitutional Preambles in Countries of Central and Southeastern Europe in the Post-communist Period, Proceedings of the Faculty of Law in Zagreb, 63, (5-6)

Jelić, Z. (2010). Natural Law and Political Economy, an Debate about the Impact of the Natural Law Doctrine on Economic Thought, Legal Life, no. 12, pp. 649-669. 
Kutlešić, V. (2010). Preambles of the Constitution - a Comparative Study of 194 positivlegal Constitutions, Annals of the Faculty of Law in Belgrade, vol. LVIII, 2.

Häberle, P. (2000). The Constitutional State, Zagreb, Political Culture.

Häberle, P (2000). Croatian Constitution (1991) in the European Legal Comparison, Croatian Political Science Review, Vol XXXVII, 1, pp. 49-55.

Hafner, P., Krstić, M. (2014). The Rational Economic Behavior - an Interdisciplinary Approach, Ekonomika, Vol. 60, october-december 2014, № 4, pp. 155-164.

Pečečin, N. (2014). On the structural-moral foundations of economic activity, Ekonomika, Vol. 60, no. 2, pp. 29-44.

Popper, K. (1993). The Open Society and Its Enemies, I, Belgrade, BIGZ

Purić, S., Djordjević, S. (2014). ECONOMIC SYSTEM IN THE CONSTITUTIONAL STRUCTURE 